\title{
Farklı Ethephon Uygulamalarının Makarnalık Buğdayda (Triticum durum L.) Bașak Özellikleri Üzerine Etkisi
}

\author{
Arzu AĞIRMATLIOĞLU MUTLU1, *Abdullah ÖKTEM² \\ ${ }^{1}$ Harran Üniversitesi Akçakale Meslek Yüksek Okulu, Șanlıurfa \\ ${ }^{2}$ Harran Üniversitesi Ziraat Fakültesi Tarla Bitkileri Bölümü, Șanlıurfa \\ *Sorumlu yazar e-posta (Corresponding author; e-mail): aoktem@harran.edu.tr
}

\section{Öz}

Bu çalıșma, 2008-2009 ve 2009-2010 yetiștirme sezonlarında Harran Ovası koșullarında yürütülmüștür. $\mathrm{Bu}$ çalıșma ile farklı dozlardaki ethephon uygulamalarının makarnalık buğday çeșitlerinin bazı bașak özellikleri üzerine etkisini belirlemek amacıyla yürütülmüștür. Aydın-93 ve Alibaba buğday çeșitleri kullanılan araștırma bölünmüș parseller deneme deseninde dört tekerrürlü olarak yürütülmüștür. Denemede dokuz ethephon dozu (0, $\left.240 \mathrm{~g} \mathrm{ha}^{-1}, 360 \mathrm{~g} \mathrm{ha}^{-1}, 480 \mathrm{~g} \mathrm{ha}^{-1}, 600 \mathrm{~g} \mathrm{ha}^{-1}, 720 \mathrm{~g} \mathrm{ha}^{-1}, 840 \mathrm{ha}^{-1}, 960 \mathrm{~g} \mathrm{ha}^{-1}, 1080 \mathrm{~g} \mathrm{ha}^{-1}\right)$ uygulanmıștır. İki yılın birleșik analiz sonuçlarına göre; ethephon uygulamalarıyla birlikte buğday çeșitlerinde bașak uzunluğu azalmıș, bașakta tane ağırlığı ve bin tane ağırlığı artmıștır. Bașak uzunluğu Aydın-93 çeșidinde $6.67 \mathrm{~cm}$ (Kontrol) ile $5.20 \mathrm{~cm}\left(960 \mathrm{~g} \mathrm{ha}^{-1}\right.$ ) arasında, Alibaba çeșidinde ise $6.46 \mathrm{~cm}$ (kontrol) ile $5.00 \mathrm{~cm}\left(1080 \mathrm{~g} \mathrm{ha}^{-1}\right)$ arasında değișmiștir. En yüksek bașakta tane ağırlığı, Aydın-93 çeșidinde $1080 \mathrm{~g}$ ha $^{-1}$ ethephon uygulamasında (2.97 g) en düșük ise kontrol uygulamasında (1.28 g); Alibaba çeșidinde ise en yüksek $1080 \mathrm{~g} \mathrm{ha}^{-1}$ ethephon uygulamasında (2.86 g), en düșük ise kontrol uygulamasında (1.30 g) görülmüștür. Bin tane ağırlığı değerleri Aydın-93 çeșidinde $38.24 \mathrm{~g}$ (kontrol) ile $49.76 \mathrm{~g}\left(960 \mathrm{~g} \mathrm{ha}^{-1}\right)$ arasında; Alibaba çeșidinde ise $37.45 \mathrm{~g}$ (kontrol) ile $49.13 \mathrm{~g}$ (1080 $\left.\mathrm{g} \mathrm{ha}^{-1}\right)$ arasında değișmiștir.

Anahtar Kelimeler: Buğday, ethephon, bașak özellikleri

\section{The Effect of Different Ethephon Dosses on Spike Characteristics of Durum Wheat (Triticum durum L.)}

\section{Abstract}

This study was carried out under supplementary irrigated conditions in the Harran Plain conditions in 2008-2009 and 2009-2010 growing seasons. The study aimed to determine the effects of various ethephon dosses on some spike characteristics of durum wheat varieties. Aydin-93 and Alibaba wheat cultivars were used as crop materials. The experimental design was established in split plots with 4 replicates. Nine ethephon dosages $\left(0,240 \mathrm{~g} \mathrm{ha}^{-1}, 360 \mathrm{~g} \mathrm{ha}^{-1}, 480 \mathrm{~g} \mathrm{ha}^{-1}, 600 \mathrm{~g} \mathrm{ha}^{-1}, 720 \mathrm{~g} \mathrm{ha}^{-1}, 840 \mathrm{~g} \mathrm{ha}^{-1}, 960 \mathrm{~g} \mathrm{ha}^{-1}, 1080\right.$ $\mathrm{g} \mathrm{ha}^{-1}$ ) were applied in the study. According to the results of the two-year combined analysis, spike length decreased but kernel weight of spike and thousand kernel weights increased with ethephon applications. Spike length varied from $6.67 \mathrm{~cm}$ (control) to $5.20 \mathrm{~cm}\left(960 \mathrm{~g} \mathrm{ha}^{-1}\right)$ in Aydin-93 variety and from $6.46 \mathrm{~cm}$ (control) to $5 \mathrm{~cm}$ (1080 $\left.\mathrm{g} \mathrm{ha}^{-1}\right)$ in Alibaba variety. The highest kernel weight of spike was found at $1080 \mathrm{~g}$ ha $^{-1}$ ethephon application $(2.97 \mathrm{~g})$ whereas the lowest value was seen at control applications $(1.28 \mathrm{~g})$ in Aydin-93 variety. The highest kernel weight of spike was found at $1080 \mathrm{~g} \mathrm{ha}^{-1}$ ethephon application (2.86 $\mathrm{g}$ ) but the lowest value was seen at control application $(1.30 \mathrm{~g})$ in Alibaba variety. Thousand kernel weights

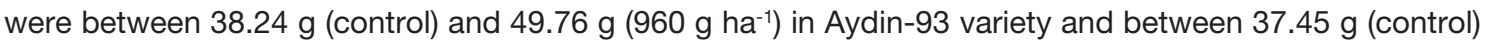
and $49.13 \mathrm{~g}\left(1080 \mathrm{~g} \mathrm{ha}^{-1}\right)$ in Alibaba variety.

Keywords: Wheat, ethephon, spike characteristics

*Bu çalıșma 26.11.2013 tarihinde Harran Üniversitesi Fen Bilimleri Enstitüsü Tarla Bitkileri Anabilim dalında kabul edilen doktora tezinin bir bölümüdür. 


\section{Giriș}

uğday dünya nüfusuna bitkisel kaynaklı besinlerden sağlanan toplam kalorinin yaklașık \%20'sini sağlamaktadır. Bu oran ülkemizde \%53’tür (Anonim 2011). Günümüzde 6.5 milyarı așan dünya nüfusunun, 2020’li yıllarda 8 milyarı bulması beklenmektedir.

Nüfustaki bu artıșa bağlı olarak; dünyada beslenme ve açlık, çok daha önemli bir sorun olarak karșımıza çıkacaktır. Islah yoluyla elde edilen bu çeșitlerin genetik yapılarındaki verim potansiyelinin ortaya çıkartılması ancak yetiștirme tekniği uygulamalarının tam olarak yerine getirilmesiyle mümkün olmaktadır (Balkan 2006).

Dziamba (1986), Lublin (Polonya) yakınında yazlık buğday çeșidine (Feeks-8 döneminde 3 litre/ha dozunda) uyguladığı Ethephon'un; verimi 0.79 ve $0.66 \mathrm{t} \mathrm{ha}^{-1}$ arttırdığını, bașak boyunu azalttığını ancak bașaktaki tane ağırığını arttırdığını tespit etmiștir.

Gendy (1991), Almanya'da Kolibriye yazlık buğday ethephon uygulamasının bașaktaki tane sayısını arttırdığını belirlemiștir. Ma ve Smith (1992), Kanada ve Quebec'te Cadette ve Leger arpa çeșitlerine üç farklı dozda ethephon $\left(0,240,480 \mathrm{~g} \mathrm{ha}^{-1}\right)$ uygulayarak yürüttüğü çalıșmada, ethephon uygulamasının 1000 tane ağırlığını her iki çeșitte ve her iki yıl da önemli derecede arttırdığını bildirmișlerdir.

Auškalniene (2005), Litvaye'de Sirvinta kışlık buğday çeşidinde ethephonun bașak uzunluğu, bașaktaki tane sayısı ve bin tane ağırlı̆ı̆ gibi parametreleri olumlu etkilediği belirtmiștir. Akçura (2001), Ethephon uygulaması ile buğdayda bașak boyunun arttığını bildirmiștir.

Aral (2001), Ankara koșullarında buğday bitkisinde ethephon uygulaması ile bașak boyunun $5.69-7,50 \mathrm{~cm}$, bin tane ağırlığının 51.50-58.20 g, bașaktaki tane ağırlı̆ı̆ının 1.64-1.99 g arasında değiștiğini; Ethephon uygulaması ile bașak uzunluğunun azaldığını, bașakta tane ağırlığı ve bin tane ağırlığının arttığını belirtmiștir.

\section{Materyal ve Yöntem}

Bu çalıșma 2008-2009 ve 2009-2010 yetiștirme sezonlarında Șanlıurfa-Harran Ovası koșullarında yürütülmüștür. Denemenin yürütüldüğü yıllara ait iklim verileri Çizelge. 1'de verilmiștir. Araștırmada Aydın-93 ve Alibaba makarnalık buğday çeșidi bitkisel materyal olarak kullanılmıștır. Aydın-93 ve Alibaba çeșitleri, yağıșlı ve sulanan koșullarda yatma eğilimi göstermektedir.

Deneme, tesadüf bloklarında bölünmüș parseller deneme desenine göre iki faktörlü (Çeșit ve ethephon uygulaması) ve dört tekerrürlü olarak yürütülmüștür. Ana parsellere çeșitler, alt parsellere ethephon dozları yerleștirilmiștir.

Ethephon [(2-chloroethyl) phosphoric asid] dozları 0, 240, 360, 480, 600, 720, 840, 960 ve $1080 \mathrm{~g} / \mathrm{ha}$ șeklinde uygulanmıștır. Ethephon bayrak yaprağı çıkıș döneminde; Feekes skalasına göre 8-9. dönemlerde (Akkaya, 1994) belirtilen dozlarda sırt pülverizatörü ile bitki yapraklarına püskürtülmüştür.

Çizelge 1. Șanlıurfa ili 2008, 2009 ve 2010 yıllarına ait bazı iklim değerleri (Anonim 2008, 2009 ve 2010). Table 1. Some climate values of Șanlıurfa for 2008, 2009 and 2010 years (Anonim 2008, 2009 and 2010).

\begin{tabular}{lcccccc}
\hline \multirow{2}{*}{ Aylar } & \multicolumn{5}{c}{ 2008-2009 } & \multicolumn{3}{c}{ 2009-2010 } \\
\cline { 2 - 6 } & Sıcaklık $\left({ }^{\circ} \mathrm{C}\right)$ & Yağıs $(\mathrm{mm})$ & Nispi nem $(\%)$ & Sıcaklık $\left({ }^{\circ} \mathrm{C}\right)$ & Yağıs $(\mathrm{mm})$ & Nispi nem $(\%)$ \\
\hline Kasım & 14.1 & 35.3 & 62.4 & 12.2 & 35.5 & 62.6 \\
Aralık & 7 & 37.7 & 58.6 & 10.1 & 121.2 & 73.4 \\
Ocak & 5.8 & 29.8 & 59.1 & 8.4 & 95.7 & 68.8 \\
Șubat & 8 & 56.6 & 72.2 & 9.1 & 23.5 & 67.4 \\
Mart & 10 & 55.3 & 65.6 & 13.8 & 42.7 & 55.7 \\
Nisan & 15.8 & 48.8 & 53 & 17.4 & 26.2 & 46.7 \\
Mayıs & 22.8 & 4.7 & 33.6 & 24 & 7.1 & 34.3 \\
Haziran & 29.6 & 9.2 & 29.2 & 29.4 & 0.5 & 31.2 \\
\hline
\end{tabular}


Çizelge 2. Farklı ethephon uygulamalarında yetiștirilen makarnalık buğday çeșitlerinin bașak uzunluğu, bașakta tane ağırlığı ve bin tane ağırlığına ilișkin varyans analizi

Table 2. Analysis of variance on the spike length, kernel weight of spike and thousand weight of durum wheat varieties grown in different ethephon applications

\begin{tabular}{|c|c|c|c|c|}
\hline & & & Kareler Ortalaması & \\
\hline Varyasyon Kaynağı & Ser. Der. & Bașak uzunluğu & Bașakta tane ağırlığı & Bin tane ağırlığı \\
\hline Yıl & 1 & $3.413^{\star \star}$ & $3.585^{\star \star}$ & 1.866 \\
\hline Tek $\times$ Yıl & 6 & 0.058 & 0.030 & 3.020 \\
\hline Çeşit & 1 & 0.016 & 0.002 & $15.821^{*}$ \\
\hline Yıl x Çeșit & 1 & 0.162 & 0.006 & 3.983 \\
\hline Hata 1 & 6 & 0.041 & 0.016 & 1.428 \\
\hline Ethephon & 8 & $4.709^{\star *}$ & $5.283^{\star *}$ & $385.368^{* *}$ \\
\hline YIl x Ethephon & 8 & 0.078 & $0.466^{\star \star}$ & $5.495^{\star \star}$ \\
\hline Çeşit x Ethephon & 8 & 0.155 & 0.019 & $3.343^{*}$ \\
\hline YIl x Çeșit x Ethephon & 8 & 0.101 & 0.016 & 1.626 \\
\hline Hata & 96 & 0.140 & 0.018 & 1.499 \\
\hline Genel & 143 & 0.406 & 3.585 & 23.489 \\
\hline
\end{tabular}

*: \%5 seviyesinde önemli, ${ }^{* *}$ : \%1 seviyesinde önemli

*: Significant at 5\%, **: significant at $1 \%$

Ekim ișlemi, 2008-2009, 2009-2010 yetiștirme sezonlarında Kasım ayı içerisinde yapılmıștır. Topraktaki elverișli nemin \%40'ı tüketildiğinde, tarla kapasitesine gelene kadar verilmesi gerekli su miktarı hesaplanarak sulama yapılmıștır (Rawlins 1976).

Taban gübresi olarak 15-15-15 kompoze gübreden dekara saf olarak $8 \mathrm{~kg} \mathrm{da}^{-1} \mathrm{NPK}$ gelecek șekilde uygulama yapılmıștır. Azot ise vejetasyon süresi boyunca $18 \mathrm{~kg} \mathrm{da}^{-1}$ olacak șekilde iki defada verilmiștir.

Üst gübre olarak da kardeşlenme döneminde dekara saf olarak $10 \mathrm{~kg} \mathrm{da}^{-1} \mathrm{~N}$ gelecek șekilde \%26'lık Amonyum Nitrat (A.N) verilmiștir. Araștırma ile ilgili gözlemlere ekimle birlikte bașlanmıș hasatla son verilmiștir. Hasat, her iki yılda da Haziran ayı içerisinde yapılmıștır.

\section{Bulgular ve Tartıșma}

Bașak uzunluğu, bașakta tane ağırlı̆̆ı ve bin tane ağırlığına ilișkin varyans analizi tablosu Çizelge 2'de verilmiștir.

\section{Bașak Uzunluğu (cm)}

Çizelge 2'de görüldüğü gibi, bașak uzunluğu bakımından yıl ve ethephon uygulamaları $\% 1$ seviyesinde istatistiki olarak önemli bulunmuștur. 2008-2009 ve 2009-2010 yıllarında Aydın-93 ve Alibaba çeșitlerinde ethephon dozu arttıkça bașak uzunluğu değerleri de artmaktadır (Çizelge 3).
İki yılın ortalamasında ise başak uzunluğu Aydın-93 çeşidinde, 5.20 (960 g ha-1 ethephon) ile $6.67 \mathrm{~cm}$ ( $0 \mathrm{~g} \mathrm{ha}^{-1}$ ethephon) arasında değișmiștir. Artan ethephon dozlarına paralel olarak bașak uzunluğundaki kısalma artmıștır. $840 \mathrm{~g} \mathrm{ha}^{-1}$ ethephon uygulamasından sonraki uygulamalarda belirgin istatistiki farklıık görülmemiștir. Alibaba çeșidinde ise bașak uzunluğu 6.46 (kontrol) ile $5 \mathrm{~cm}$ (1080 g ha-1 ethephon) arasında değișmiștir.

Ethephon uygulamasının $0 \mathrm{~g} \mathrm{ha}^{-1}$ olduğu uygulamada en yüksek, $1080 \mathrm{~g} \mathrm{ha}^{-1}$ olduğu uygulamada ise en düșük bașak uzunluğu değerleri elde edilmiștir. Ancak 480 ile $600 \mathrm{~g}$ ha $^{-1}$ ethephon uygulamaları aynı grupta, 840 ile $960 \mathrm{~g} \mathrm{ha}^{-1}$ ethephon uygulamaları aynı grupta yer almıș ve istatistiki yönden aralarında bir fark bulunmamıștır. Her iki yılda da ethephon uygulama dozlarının artıșıla birlikte bașak uzunluğunun azaldığı görülmüștür (Șekil 1). Buğday bitkisinde ethephon uygulaması ile bașak uzunluğunun azaldığı bazı araștırıcılar tarafından da bildirilmektedir (Gendy 1991; Auskalniene 2005; Aral 2001; Akçura 2001; Dziamba 1986).

\section{Bașakta Tane Ağırlığı (g)}

Çizelge 2'de görüldüğü gibi bașakta tane ağırlığı bakımından yıl, ethephon uygulamaları, $y$ Il $x$ ethephon uygulamaları \%1 seviyesinde istatistiki olarak önemli bulunmuștur 20082009 ve 2009-2010 yıllarında Aydın-93 ve Alibaba çeșitlerinde ethephon dozu arttıkça 
Çizelge 3. Farklı ethephon uygulamalarında yetiștirilen makarnalık buğday çeșitlerinin bașak uzunluğu, bașakta tane ağırlığı ve bin tane ağırlığı değerleri ve olușan LSD grupları

Table 3. The spike length, kernel weight of spike and thousand weight values and LSD groups of durum wheat varieties grown in different ethephon applications

\begin{tabular}{|c|c|c|c|c|c|c|c|c|c|c|}
\hline \multirow[b]{2}{*}{ Çeşit } & \multirow[b]{2}{*}{$\begin{array}{c}\text { Ethephon } \\
\text { Dozları } \\
\left(\mathrm{g} \mathrm{ha}^{-1}\right)\end{array}$} & \multicolumn{3}{|c|}{ Bașak Uzunluğu (cm) } & \multicolumn{3}{|c|}{ Bașakta Tane Ağırlığı (g) } & \multicolumn{3}{|c|}{ Bin Tane Ağırlığı (g) } \\
\hline & & 2008-09 & $2009-10$ & Ort. & 2008-09 & $2009-10$ & Ort. & 2008-09 & $2009-10$ & Ort. \\
\hline \multirow{9}{*}{ 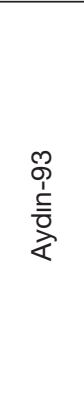 } & 0 & $6.830 \mathrm{a}^{*}$ & $6.520 \mathrm{a}$ & $6.68 \mathrm{a}$ & $1.388 h^{*}$ & $1.188 \mathrm{e}$ & 1.29 & $37.198 \mathrm{~d}$ & $39.250 \mathrm{e}$ & $38.24 \mathrm{e}$ \\
\hline & 240 & $6.890 \mathrm{a}$ & $6.165 a b$ & $6.53 a b$ & $1.593 \mathrm{~g}$ & $1.453 \mathrm{~d}$ & 1.52 & $38.363 \mathrm{~d}$ & $40.168 \mathrm{e}$ & $39.27 \mathrm{de}$ \\
\hline & 360 & $6.293 \mathrm{~b}$ & $6.020 \mathrm{abc}$ & $6.16 \mathrm{bc}$ & $1.772 \mathrm{fg}$ & $1.608 \mathrm{~cd}$ & 1.69 & $38.400 \mathrm{~d}$ & $40.735 \mathrm{e}$ & $39.57 \mathrm{~d}$ \\
\hline & 480 & $6.278 \mathrm{~b}$ & $5.828 \mathrm{bc}$ & $6.05 \mathrm{~cd}$ & 1.9185 ef & $1.778 \mathrm{c}$ & 1.85 & $40.348 c$ & $42.815 d$ & $41.58 \mathrm{c}$ \\
\hline & 600 & $5.940 \mathrm{bc}$ & $5.563 \mathrm{~cd}$ & $5.75 d$ & $2.074 \mathrm{e}$ & $1.988 \mathrm{~b}$ & 2.03 & $46.643 \mathrm{~b}$ & $46.215 c$ & $46.43 \mathrm{~b}$ \\
\hline & 720 & $5.360 \mathrm{~d}$ & $5.098 \mathrm{de}$ & $5.23 \mathrm{e}$ & $2.588 d$ & $2.478 \mathrm{a}$ & 2.53 & $49.535 \mathrm{a}$ & $47.810 \mathrm{bc}$ & $48.67 \mathrm{a}$ \\
\hline & 840 & $5.345 d$ & $5.095 \mathrm{de}$ & $5.22 \mathrm{e}$ & $2.781 \mathrm{c}$ & $2.500 \mathrm{a}$ & 2.64 & $49.483 \mathrm{a}$ & $49.645 \mathrm{a}$ & $49.56 \mathrm{a}$ \\
\hline & 960 & $5.345 \mathrm{~d}$ & $5.068 \mathrm{de}$ & $5.21 \mathrm{e}$ & $3.092 b$ & $2.455 \mathrm{a}$ & 2.77 & $50.328 \mathrm{a}$ & $49.207 a b$ & $49.77 \mathrm{a}$ \\
\hline & 1080 & $5.445 \mathrm{~cd}$ & $4.995 \mathrm{e}$ & $5.22 \mathrm{e}$ & $3.453 \mathrm{a}$ & $2.490 \mathrm{a}$ & 2.97 & $50.035 \mathrm{a}$ & $49.488 a b$ & $49.76 \mathrm{a}$ \\
\hline \multicolumn{2}{|c|}{ Ortalama } & 5.969 & 5.594 & 5.78 & 2.296 & 1.993 & 2.14 & 44.481 & 45.041 & $44.76 \mathrm{~A}$ \\
\hline \multirow{9}{*}{$\begin{array}{l}\frac{\pi}{0} \\
\frac{\pi}{\pi} \\
\frac{0}{\bar{\alpha}}\end{array}$} & 0 & $6.758 \mathrm{a}$ & $6.165 \mathrm{a}$ & $6.46 \mathrm{a}$ & $1.405 \mathrm{~h}$ & $1.205 \mathrm{e}$ & 1.30 & $37.135 \mathrm{f}$ & $37.765 \mathrm{f}$ & $37.45 f$ \\
\hline & 240 & $6.640 \mathrm{a}$ & $6.245 \mathrm{a}$ & $6.44 \mathrm{a}$ & $1.603 \mathrm{~g}$ & $1.500 \mathrm{~d}$ & 1.55 & $37.155 f$ & $38.155 f$ & $37.66 \mathrm{f}$ \\
\hline & 360 & $6.380 \mathrm{ab}$ & $5.985 \mathrm{a}$ & $6.18 \mathrm{ab}$ & $1.740 \mathrm{~g}$ & $1.7 .53 \mathrm{c}$ & 1.75 & $40.395 \mathrm{e}$ & $39.938 f$ & $40.17 \mathrm{e}$ \\
\hline & 480 & $5.988 \mathrm{bc}$ & $5.858 \mathrm{ab}$ & $5.92 \mathrm{bc}$ & $1.928 \mathrm{f}$ & $1.885 \mathrm{c}$ & 1.91 & $41.885 \mathrm{e}$ & $43.085 \mathrm{~d}$ & $42.49 \mathrm{~d}$ \\
\hline & 600 & $5.925 \mathrm{bc}$ & $5.773 a b c$ & $5.85 \mathrm{bc}$ & $2.134 \mathrm{e}$ & $2.090 \mathrm{~b}$ & 2.11 & $44.558 \mathrm{c}$ & $44.960 \mathrm{c}$ & $44.76 \mathrm{c}$ \\
\hline & 720 & $5.763 \mathrm{c}$ & $5.400 \mathrm{bcd}$ & $5.58 \mathrm{~cd}$ & $2.565 d$ & $2.358 \mathrm{a}$ & 2.46 & $47.578 \mathrm{~b}$ & $46.760 \mathrm{~b}$ & $47.17 \mathrm{~b}$ \\
\hline & 840 & $5.473 \mathrm{c}$ & $5.290 \mathrm{~cd}$ & $5.38 \mathrm{~d}$ & $2.835 \mathrm{c}$ & $2.353 \mathrm{a}$ & 2.59 & $49.763 a b$ & $48.133 a b$ & $48.95 \mathrm{a}$ \\
\hline & 960 & $5.543 \mathrm{c}$ & $5.260 \mathrm{~cd}$ & $5.40 \mathrm{~d}$ & $3.071 \mathrm{~b}$ & $2.310 \mathrm{a}$ & 2.69 & 49.578 a & $48.665 \mathrm{a}$ & $49.12 \mathrm{a}$ \\
\hline & 1080 & $4.842 \mathrm{~d}$ & $5.168 \mathrm{~d}$ & $5.01 \mathrm{e}$ & $3.434 \mathrm{a}$ & $2.302 \mathrm{a}$ & 2.87 & $49.313 \mathrm{a}$ & $48.953 \mathrm{a}$ & $49.13 \mathrm{a}$ \\
\hline \multicolumn{2}{|c|}{ Ortalama } & 5.923 & 5.683 & 5.80 & 2.301 & 1.973 & 2.14 & 44.15 & 44.151 & 44.05 \\
\hline \multicolumn{2}{|c|}{ YIl Ort. } & $5.946 \mathrm{~A}$ & $5.638 \mathrm{~B}$ & 5.79 & $2.30 \mathrm{~A}$ & $1.983 \mathrm{~B}$ & 1.98 & 44.32 & 44.316 & 44.54 \\
\hline
\end{tabular}

YII LSD: 0.083, Çeșit x Doz LSD: 0.372, YII x Çeșit x Doz LSD: 0.526 (Bașak uzunluğu)

Çeşit*Doz LSD: 2.008, Yı।* Çeşit*Doz LSD: 2.839 (Başakta tane ağırlığı)

Çeşit LSD: 0.488, Çeşit*Doz LSD: 1.217 Y. ${ }^{*}$ Çeşit ${ }^{*}$ Doz LSD: 1.721 (Bin tane ağırlığı)

*: Aynı sütunda aynı harf grubuna giren ortalamalar arasında 0,05 seviyesinde önemli farklllık yoktur

Year LSD:0.083, Variety x Dosage LSD:0.372, Year x Variety x Dosage LSD: 0.526 (Spike lenght)

Variety*Dosage LSD:2.008, Year*Variety*Dosage LSD: 2.839 (kernel weight of spike)

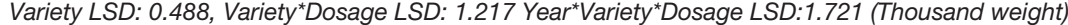

*: There is no significant difference in 0.05 level between the averages entering the same letter group

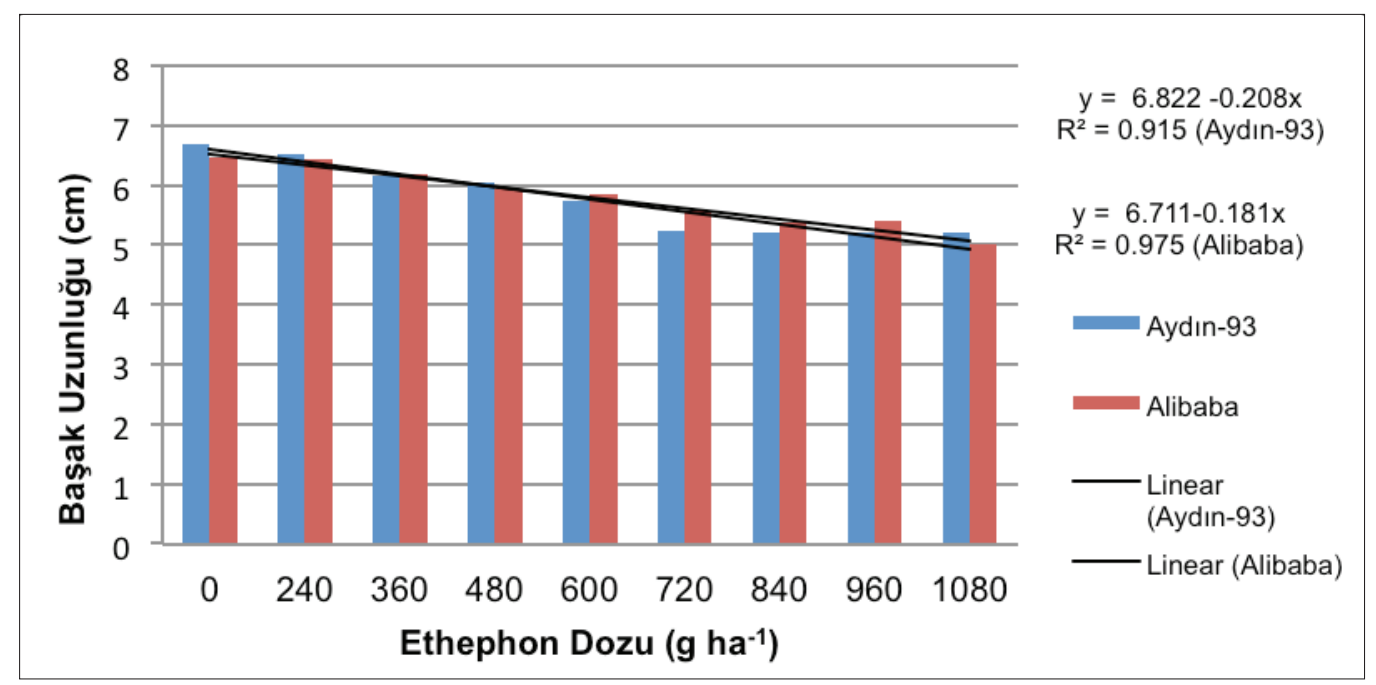

Șekil 1. Farklı ethephon uygulamalarında makarnalık buğday çeșitlerinin bașak uzunluğu değerleri. Figure 1. Spike length values of durum wheat varieties grown in different ethephon applications 


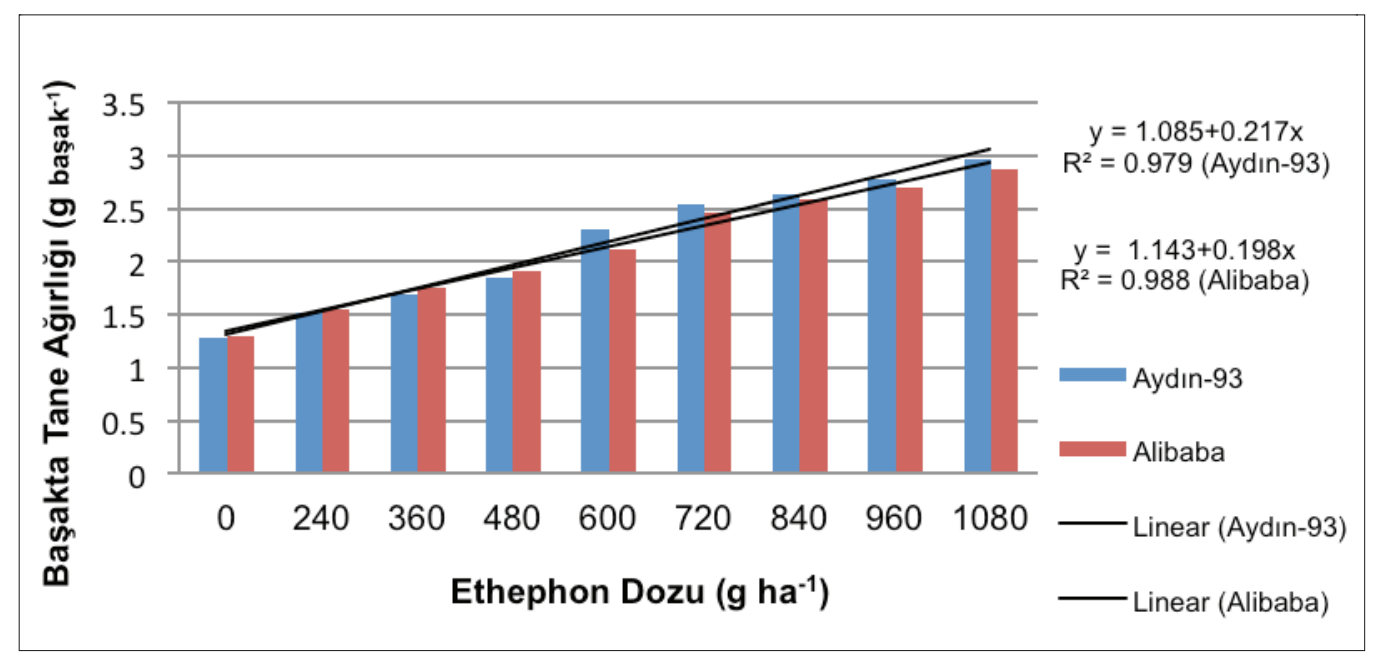

Șekil 2. Farklı ethephon uygulamalarında makarnalık buğday çeșitlerinin bașakta tane ağırlığı değerleri.

Figure 2. Kernel weight of spike values of durum wheat varieties grown in different ethephon applications

bașak ağırlığı değerleri de artmaktadır (Çizelge 3).

İki yılın ortalamasında ise, bașakta tane ağırlığı değeri Aydın-93 çeșidinde $1.28 \mathrm{~g}$ (0 g $\mathrm{ha}^{-1}$ ethephon) ile $2.97 \mathrm{~g}$ (1080 $\left.\mathrm{g} \mathrm{ha}^{-1}\right)$ arasında değișmiștir. Alibaba çeșidinde ise bașakta

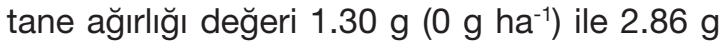
(1080 $\mathrm{g} \mathrm{ha}^{-1}$ ) arasında değișmiștir. Ethephon uygulamasının $0 \mathrm{~g} \mathrm{ha}^{-1}$ olduğu uygulamada en düșük, $1080 \mathrm{~g} \mathrm{ha}^{-1}$ olduğu uygulamada ise en yüksek bașakta tane ağırlığı değerleri elde edilmiștir.

İki yılın ortalamasında çeşit $x$ ethephon dozu interaksiyonunda ise Aydın-93 $\times 0 \mathrm{~g} \mathrm{ha}^{-1}$ (1.28 g) kombinasyonunda en düșük, Aydın-93 $x 1080 \mathrm{~g} \mathrm{ha}^{-1}$ (2.97 g) kombinasyonunda ise en yüksek bașakta tane ağırlığı değerine ulașılmıștır (Șekil 2). Buğday bitkisinde ethephon uygulaması ile bașak uzunluğunun kısaldığı bașakta tane ağırlığı değerinin arttığı bazı araștırıcılar tarafından da bildirilmektedir (Auškalniene 2005; Ahmed ve Jama 2007: Akçura 2001 ve Aral 2001).

\section{Bin Tane Ağırlığı (g)}

Çizelge 2'de görüldüğü gibi bin tane ağırlığı bakımından çeșit ve çeșit $x$ ethephon uygulamaları \%5, ethephon uygulamaları, yı $x$ ethephon uygulamaları, \%1 seviyesinde istatistiki olarak önemli bulunmuștur. 20082009 ve 2009-2010 yıllarında Aydın-93 ve
Alibaba çeșitlerinde ethephon dozu arttıkça bin tane ağırlığı değerleri de artmaktadır (Çizelge 3).

İki yılın ortalamasında bin tane ağırlığı

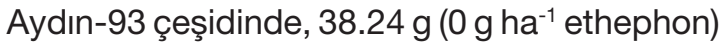
ile $49.76 \mathrm{~g}$ (960 $\mathrm{g} \mathrm{ha}^{-1}$ ethephon) arasında değișmiștir. Artan ethephon dozlarına paralel olarak bin tane ağırlığı değerleri de artmıștır. Alibaba çeșidinde ise bin tane ağırlığı değeri

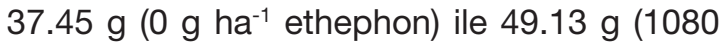
$\mathrm{g} \mathrm{ha}{ }^{-1}$ ethephon) arasında değișmiștir (Șekil 3). Ethephon uygulamasının $0 \mathrm{~g} \mathrm{ha}^{-1}$ olduğu uygulamada en düșük, $1080 \mathrm{~g} \mathrm{ha}^{-1}$ olduğu uygulamada ise en yüksek bin tane ağırlığı değerleri elde edilmiștir.

Herikiyıldadaethephonuygulamadozlarının artıșıyla birlikte bin tane ağırlığı değerleri de artmıștır. Akçura (2001), ethephonun bin tane ağırlığını kontrole göre arttırdığını belirlemiștir. Buğday bitkisinde ethephon uygulaması ile bin tane ağırlığının arttığı bazı araștırıcılar tarafından bildirilmektedir (Ma ve Smith 1992; Aral 2001; Auškalniene 2005).

\section{Sonuç}

Ethephon uygulamalarıyla birlikte buğday çeșitlerinde bașak uzunluğu azalmıș, bașakta tane ağırlığı ve bin tane ağırlığı artmıștır. Bașak uzunluğu Aydın-93 çeșidinde 6.67 cm (Kontrol) ile $5.20 \mathrm{~cm}$ (960 $\mathrm{g} \mathrm{ha}^{-1}$ ) arasında, Alibaba çeșidinde ise $6.46 \mathrm{~cm}$ (kontrol) ile $5 \mathrm{~cm}(1080$ $\mathrm{g} \mathrm{ha}^{-1}$ ) arasında değișmiștir. 


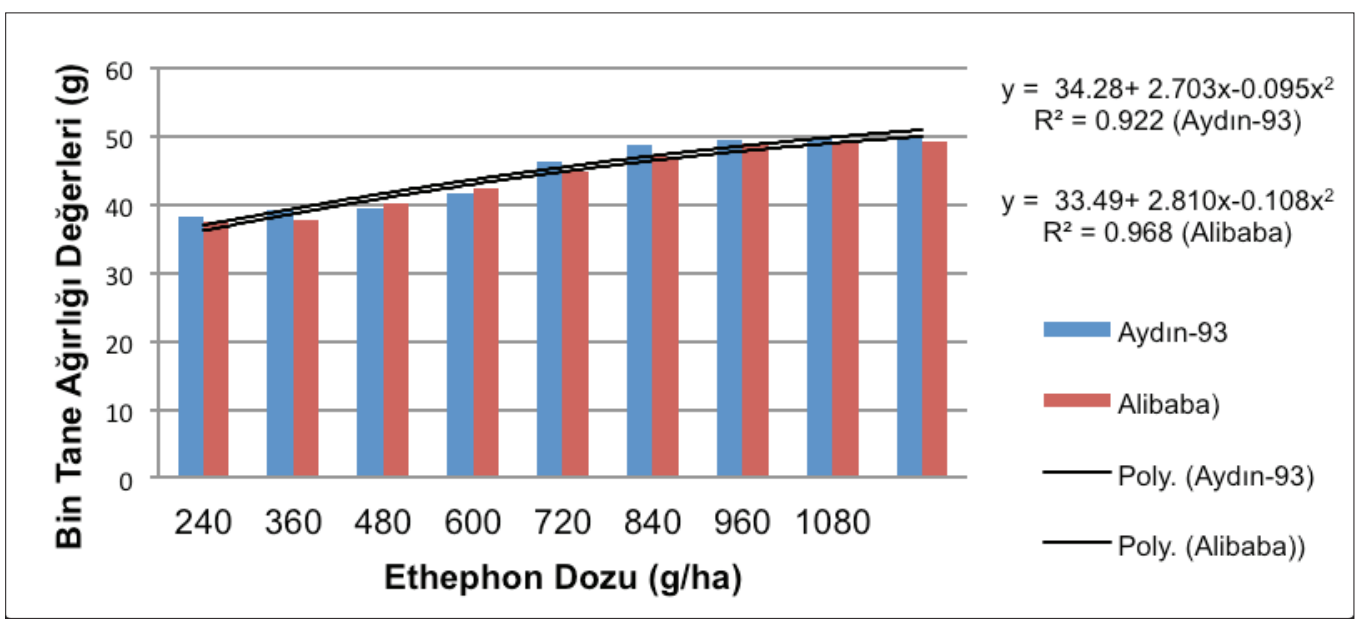

Șekil 3. Farklı ethephon uygulamalarında makarnalık buğday çeșitlerinin bin tane ağırlığı değerleri. Figure 3. Thousand weight of durum wheat varieties grown in different ethephon applications

En yüksek bașakta tane ağırlığı, Aydın-93 çeșidinde $1080 \mathrm{~g} \mathrm{ha}^{-1}$ uygulamasında (2.97 g), en düșük ise kontrol uygulamasında (1.28 g); Alibaba çeșidinde ise en yüksek $1080 \mathrm{~g} \mathrm{ha}^{-1}$ ethephon uygulamasında ( $2.86 \mathrm{~g})$, en düșük ise kontrol uygulamasında (1.30 g) görülmüștür.

Bin tane ağırlığı değerleri Aydın-93 çeșidinde $38.24 \mathrm{~g}$ (kontrol) ile $49.76 \mathrm{~g}$ (960 $\mathrm{g} \mathrm{ha}^{-1}$ ) arasında; Alibaba çeșidinde ise $37.45 \mathrm{~g}$ (kontrol) ile $49.13 \mathrm{~g}$ (1080 $\mathrm{g} \mathrm{ha}^{-1}$ ) arasında değișmiștir.

Ethephon uygulamalarıyla birlikte makarnalık buğday çeșitlerinde bașak uzunluğu azalmıș, bașakta tane ağırığı ve bin tane ağırlığı artmıștır.

\section{Kaynaklar}

Ahmed A.T.J. and Jama Y.A., 2007. Effects of water stress conditions and plant growth regulators on growth, yield and yield components in durum wheats (Triticum turgidum L. var. durum) under the Jordan conditions. Journal of Agronomy, 6 (1): 100-105

Akçura M., 2001. Kahramanmaraș koșullarında farklı dozlarda ethephon, chlormepiquat chloride ve ethephon+chlormepiquat chloride kullanımının bazı ekmeklik buğday (Triticum aestivum I.) genotiplerinde verim ve verim unsurları üzerine etkisi. KSÜ Fen Bil. Enst. Yüksek Lisans Tezi, Tez No: 105870, Kahramanmaraș, 53s

Akkaya A., 1994. Buğday Yetiștiriciliği. Kahramanmaraș Sütçü İmam Üniversitesi Ziraat Fakültesi Yayınları, No: 1, Kahramanmaraș, 225s
Anonim 2008. Meteoroloji genel müdürlüğü 2008 yılı Șanlıurfa ili iklim verileri

Anonim 2009. Meteoroloji genel müdürlüğü 2009 yılı Șanlıurfa ili iklim verileri

Anonim 2010. Meteoroloji genel müdürlüğü 2010 yılı Șanlıurfa ili iklim verileri

Anonim 2011. Yetiștiricilik / Hububat Yetiștiriciliği. https://www.tarimziraat.com/Aral M., 2001. Makarnalık buğdaya (Triticum durum L. desf.) uygulanan ethephonun verim ve verim öğelerine etkisi. Ankara Üniversitesi Fen Bilimleri Enstitüsü Yüksek Lisans Tezi, Tez No: 104363, 87s

Auškalnienè O., 2005. The influence of modus mixtures with other plant growth regulators on the grain yield and productivity of winter wheat. Žemdirbystè, Mokslodarbai, 90: 48-60

Balkan A., 2006. Bazı ekmeklik buğday (Triticum aestivum) çeșitlerinde farklı sıra arası ve tohumluk miktarının verim ve kalite unsurlarına etkileri. Trakya Üniversitesi Fen Bilimleri Enstitüsü Yüksek Lisans Tezi, Tez No: 183899, 162s

Dziamba S., 1986. The effect of flordimex on yields of triticale, rye and wheat as related to the level of mineral fertilization. Acta Agraria et Silvestria, 25: $141-156$

Gendy A., 1991. Ear development of spring wheat by combined application of CCC, $\mathrm{DCiB}$ and ethephon. Beiträge zur Tropischen Landwirtschaft und Veterinärmedizin, 29 (1): 5156

Ma B.L. and Smith D.L., 1992. Post-anthesis ethephon effects on yield of spring barley. American Society of Agronomy, 84: 370-374

Rawlins S.L., 1976. Measurement of water content and the state of water in soils. p.1-55. In: T. T. Kozlowski, editor. Water Deficits and Plant Growth. Academic Press, NY, 4: 1-55 